\title{
Genetic Analysis of Itchy Leaves (Laportea, sp) in Papua for Herbal Medicinal Products as Development of Studying Economics Value
}

\author{
Elda Kristiani Paisey ${ }^{1}$, Yaved Muyan'1, Desi Natalia Edowai ${ }^{2}$, Muhammad Dailami $^{3}$ \\ ${ }^{1}$ Agriculture Faculty, University of Papua, Manokwari, Indonesia \\ ${ }^{2}$ Faculty of Agriculture Technology, University of Papua, Manokwari, Indonesia \\ ${ }^{3}$ Faculty of Mathematics and Sciences, University of Papua, Manokwari, Indonesia \\ Email: elda.kristiani@yahoo.co.id
}

How to cite this paper: Paisey, E.K., Muyan, Y., Edowai, D.N. and Dailami, M. (2017) Genetic Analysis of Itchy Leaves ( $\mathrm{La}$ portea, sp) in Papua for Herbal Medicinal Products as Development of Studying Economics Value. Natural Science, 9, 31-41. https://doi.org/10.4236/ns.2017.92004

Received: October 27, 2016

Accepted: February 24, 2017

Published: February 27, 2017

Copyright ( 92017 by authors and Scientific Research Publishing Inc. This work is licensed under the Creative Commons Attribution International License (CC BY 4.0).

http://creativecommons.org/licenses/by/4.0/

\begin{abstract}
Papua is rich in biodiversity. The indigenous Papuans utilize most of endemic plants as food, board and medicines. One of the plants used as medicine is Laportea, sp, that locally known as Daun Gatal. The plant however, has not been developed commercially; this might due to lack of scientific providence of medicine content in this plant. The aims of this research is to (1) explore the types of Laportea growing in Papua, (2) conduct bio molecular character, which observes phylogeny relationship or genetic morphology in order to obtain data on the number of species found in Manokwari and Nabire. Bio molecular analysis is performed by PCR. Genetic analysis in this study was conducted through several phases, as follow: (a) Isolation of genomic total, (b) amplification of genes that encoded Rbcl, (c) sequencing the nucleotide sequence of the gene Rbcl of Laportea, (d) phylogeny analysis. The results showed that the DNA quality was good enough to do the next analysis. Of the four samples, two obtained haplo types are Haplo Type 1 (DT.NBX.H, DT.NBX.U and DR.MKW.H) and Haplo Type 2 (DR.NBX.L). The results of the analysis of phylogeny trees showed samples at 1 in the same haplo type, clade sequences of the genus Dendrocnide spp, Discocnide, and Laportea, while the sample at 2 in the same haplotype clade with Laportea interupta, Laportea ruderalis and Urera sp.
\end{abstract}

\section{Keywords}

Genetics, Medicinal Herbs, Daungatal (Laportea, sp)

\section{Introduction}

Indonesia is a country that is extremely rich in biodiversity of medicinal plants 
and it is potential to be developed. There are about 30.000 species of plants of the world's total of 40.000 plant species and 940 types are medicinal plants. This amount represents $90 \%$ of the medicinal plants in Asia. Many types of new drugs $20 \%-22 \%$ plants were cultivated, while around $78 \%$ was obtained through direct retrieval (exploration) of forest [1].

Papua is part of east Indonesia. It obtains a huge number of biological state, which is about $20.000-25.000$ species of plants and 142 species of them are endemic Papua [2]. The indigenous people of Papua utilize these plants as food, board and medicines. One of the plants used as medicine is Laportea, sp, the Papuan people called daun gatal and scientifically known as Laportea, sp.

The results showed that laportea Decumana (Roxb) Wed was positive for alkaloids, glycocides, steroids/triterpenoids and negative for saponis, flavonoids and tannins [3]. Then formic acid was influencing the regardless pore dilation thus stimulating blood circulation to relieve aches. In addition to the tribe, some of $\mathrm{La}$ portea are also used to relieve nausea or dizziness pat on the head, and relief pain during child birth.

This plant is utilized by nearly all the tribes in Papua. This plant grows in the highlands and lowlands. Utilization is only through direct exploration of nature without a process of cultivation. Based on research of population under the plant, there are three types of laportea, but until now there has been no study of bio molecular about all three types of plants, while according to Esiett, et al. [4], the Family of Urticaceae consists of 22 species. Therefore, it is necessary to conduct a study to analyze the molecular of Laportea in Papua. This study aims to (1) perform the ekspolrasi types of Laportea that grows in Papua, (2) do character the biomolecular, (3) obtain teaching materials for lectures stratum-1 and (4) disseminate the results of research in the national journal accredited or international Journal.

Laporeta have wide deployment; this plant grows in almost all regions. But until now, there has not been known how many species are found in Papua and which type has the highest content. Therefore, knowing the type and content of the highest is the target of this research.

Laportea used by Papuans as pharmaceuticals but until now there has been much research done on this plant and is not engaged in a professional manner. Laportea Commercialized in the market at a price of 5000 rupiah for $5-10$ pieces. Commercialized parts of the plant are the leaves of of Laportea. Laportea leaves are commercialized taken directly from nature without cultivation that need to be developed with input cultivation of this plant fertilization can increase the content of useful is the target of this research. Harvesting of medicinal plants directly from natural habitat has threatened the conservation of several species of medicinal plants [5]. There are 55 species of medicinal plants are scarce in Indonesia with the status of scarcity [6].

Currently, the needs of herbal medicines is increasing, this is due to the lack of side effects from the use of herbal remedies based on Ditjen PEN, 2014. Industrial development of medicinal plant raw material in the last 5 years has shown 
significant growth and earnings of production during this period increased by $2.5 \%-30 \%$ /year. Therefore, the lack of scientific information about this plant it is important to conduct research on plants of Laportea assessment form that plants in Papua.

\section{Materials and Methods}

\subsection{Sample Collection}

The leaves were collected from Manokwari (West Papua Province) and Nabire (Papua Province). Fresh leaves were preserved and dried quickly by using silica gel.

\subsection{Genomic DNA Isolation}

Total genome of the sample leaf was isolated with Genomic DNA mini kit (plant), Geneaid, by using standard protocol of the product. Shortly, the DNA isolation was done by taking approximately $50-100 \mathrm{mg}$ of sample and grinding with sterile mortar. The grinded sample was added to the lysis buffer GPX1 $(400 \mu \mathrm{L})$. To degrade the RNA, RNA-se was added to the solution and incubated at $65^{\circ} \mathrm{C}$ for five minutes. Before filtration, $100 \mu \mathrm{L}$ of GP2 buffer was added then leaved on ice for three minutes. Filtration on filter column with centrifuge at $3500 \mathrm{rpm}$ for 1 minutes. Supernatant of the filtrate was transferred to new micro centrifuge tube $1.5 \mathrm{~mL}$. Then, buffer GP3 (1.5 times volume of supernatant) was mixed with the solution by vortex. The mixture was transferred to the GD column and centrifuge at 15,000 rpm for two minute. The GD column was washed with W1 buffer $(400 \mu \mathrm{L})$ and wash buffer $(600 \mu \mathrm{L})$ and each step was centrifuged at 15,000 rpm for 30 seconds. To dry the column, it was centrifuge at 15,000 rpm for three minutes. DNA genome that attached to the column was eluted with heated elution buffer $(100 \mu \mathrm{L})$. The column and elution buffer were incubated at room temperature for three minutes to let the elution buffer interact with the DNA, then centrifuged at 15,000 rpm for 30 seconds. The extract DNA was kept in freezer.

\subsection{Amplification of Ribulose 1,5 Difosfat Carboxylase Large Subunit Gene (rbcL)}

Amplification of rbcL gen from gatal leaf was done with polymerase chain reaction (PCR) by using thermal cycler machine MJ mini thermocycler, model TN 1148, Biorad. The primer used were rbcLaF (5'-ATGTCACCACAAACAGAGACTAAAGC-3') (Levin et al. 2003) and rbcLaR (5'-GTAAAATC AAGTCCACCRCG-3') (Kres et al. 2009). The PCR reagents were Go-Taq-Green Master mix kit, Promega. PCR reaction was conducted in total volume $50 \mu \mathrm{L}$, that consist of 18 $\mu \mathrm{L} \mathrm{ddH}_{2} \mathrm{O}, 25 \mu \mathrm{L}$ Go-Taq-Green master mix, $2.5 \mu \mathrm{L}$ of primer rbcLaF, $2.5 \mu \mathrm{L}$ of primer rbcLaR, and $1 \mu \mathrm{L}$ of DNA genomic extract. The temperature profile of the PCR machine was $80^{\circ} \mathrm{C}$ for 10 seconds, $94^{\circ} \mathrm{C}$ for 2 minutes, then followed by 35 cycle of 3 steps which were $\left(94^{\circ} \mathrm{C}\right.$ for 30 seconds, $50^{\circ} \mathrm{C}$ for 30 seconds and $72^{\circ} \mathrm{C}$ for 1 minute), the final extension at $72^{\circ} \mathrm{C}$ for 5 minute, then closed with $37^{\circ} \mathrm{C}$ for one minute. 


\subsection{Electrophoresis}

The visualization of PCR product was done by electrophoresis gel agarose $1 \%$ with sodium boric buffer and voltage $100 \mathrm{~V}$ for 30 minutes. Each well consist of $4 \mu \mathrm{L}$ PCR product and $1 \mu \mathrm{L}$ of loading dye. As the marker, Generuller $1 \mathrm{~Kb}$ DNA ladder (Thermoscientific) was used. The dying of DNA was conducted by immersing the gel on ethidium bromide solution for 20 minutes and visualize with UV-transilluminator. The gel was documented by digital camera.

\subsection{Sequencing}

The sequencing of rbcL genes is conducted by dideoxy termination sanger. The process was done by company service, PT. Genetika Science Indonesia, Jakarta. The electropherogram in AB1 format sent by email.

\subsection{Data Analysis}

The sequence of rbcL gene was proof read with the electropherogram with MEGA 5 software [7]. Basic local search alignment tools (BLAST) from NCBI was used to compare our data with the GenBank data (NCBI). Phylogenetic tree analysis (neighbor joining and maximum likelihood) was made with MEGA 5 software. The bootstrap support in each branch was calculated by bootstrap methods with 1000 replication.

\section{Results and Discussion}

\subsection{The Spread Pattern of Laportea Spin Nabire and Manokwari Regency}

Based on the results of research conducted in the regency of Manokwari and Nabire result that daungatal or by the Latin name is Laportea sp, there is widespread in lowland up to the highland, the deployment begins at a height of 50 meters above sea level to 1500 meters above sea in the Manokwari regency. Laportea plants live in secondary forest and primary forest. In the primary forest, these plants live under stands of large trees with wet environmental conditions but dry land and have plenty of humus. This is consistent with the statement of the WHO [8] that this Laportea plant habitats in the shade and grows well in wet areas but with the dry land. In addition, this plant has been cultivated by some local communities in Manokwari in the yard of the house, where in addition to the needs of family medicine this plant is also traded in the market for profit. Similarly, in the Nabire regency, based on the exploration results obtained plants Laportea were living in primary forests and secondary forests that spread from the lowlands to the highlands of the area Wanggar-Lagari until the Topo-Dogiyai, which ranges at an altitude of 65 masl to 1300 masl. This plant in Nabire is not cultivated by the community because this plant grows wild and naturally so that the beneficiaries are taken directly from nature.

From the results of exploration in Manokwari and Nabire obtained some kind of Laportea. Based on altitude, in the district of Manokwari in the lowlands, three plant species of Laportea are found by the local name Consist thin daungatal, red 
and the Laportea pig. While in the highlands also found that living plants of the Laportea that leaves itchy scratchy thin and red leaves. Based on the exploration results in Nabire, in the lowlands found three types of laportea living is based on local names gatel leaves, leaf green and Laportea scratchy purple, while living on the plateau that leaves itchy scratchy green and purple leaves. Leaf morphology itchy red and green leaves and flowers are shown in Figure 1.

\subsection{Molecular Genetic Analysis}

\subsubsection{Genomic DNA of Laportea, Isp}

A total of six samples of Laportea from Nabire and Manokwari (Table 1), has isolated its genome DNA by using genomic geneaid isolation kit (plant). The success of the isolation of genomic DNA is shown with their band on a $1 \%$ agarose gel electrophoresis. Sightings DNA bands of the six samples are presented in Figure 2.

Based on the results of electrophoresis in Figure 2, seen all the DNA samples had white ribbons lengthwise. The quality of the sample genome DGR.MKW.H are very good with a very thick color, which indicates the concentration of DNA obtained is very high. Other samples had sufficient quality to be used in the PCR process.

\subsubsection{Amplicon Gene Ribulose-1,5-Bisphosphate-Carboxylase (Rbcl)}

Gen $\mathrm{Rbcl}$ of Laportea in the leaf samples in vitro amplification using polymerase chain reaction (PCR). Primary used is Rbcl-Ar [9] and Rbcl-Af [10]. Electrophoresis was performed using $1 \%$ agarose gel. As the marker (marker) used DNA marker $1 \mathrm{~kb}$. Long amplicons obtained had a size of about $400 \mathrm{bp}$. With DNA quality was very good with high levels of brightness, brighter in the DNA bands in DNA marker which has a concentration of $70 \mathrm{ng} / \mathrm{uL}$ for most bright ribbon of DNA markers. This means that the DNA amplicon concentration higher than 70 $\mathrm{ng} / \mathrm{uL}$. This concentration is enough to be used in the sequencing stage. The results of electrophoresis of products PCR can be seen in Figure 3.

Electrophoresis results showed that there were four samples were successfully
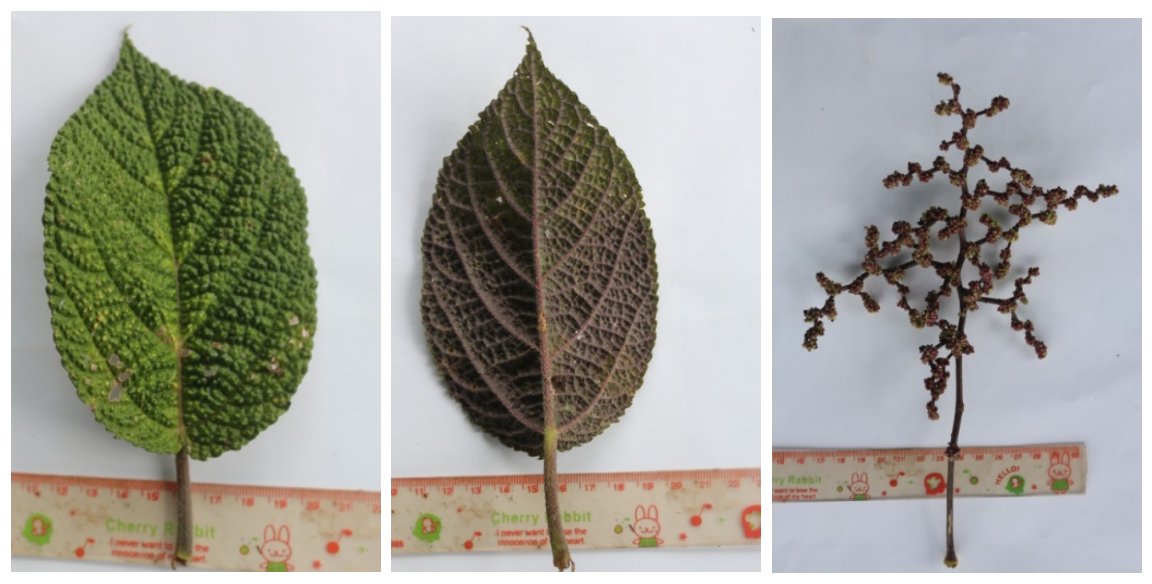

Figure 1. Morphological of Plant Laportea sp living in primary forests Okabai, Topo district of Nabire Regency. 
Table 1. List of samples used in molecular genetic analysis.

\begin{tabular}{ccc}
\hline ID Sampel & Jenis & Lokasi \\
\hline DGT.NBX.H & Daun gatal hijau & Dataran Tinggi Nabire \\
DGT.NBX.U & Daun gatal ungu & Dataran Tinggi Nabire \\
DGR.NBX.L & Daun gatal lateng & Dataran Tinggi Nabire \\
DGR.MKW.B & Daun gatal babi & Dataran Rendah Manokwari \\
DGR.MKW.H & Daun gatal hijau & Dataran Rendah Manokwari \\
\hline
\end{tabular}

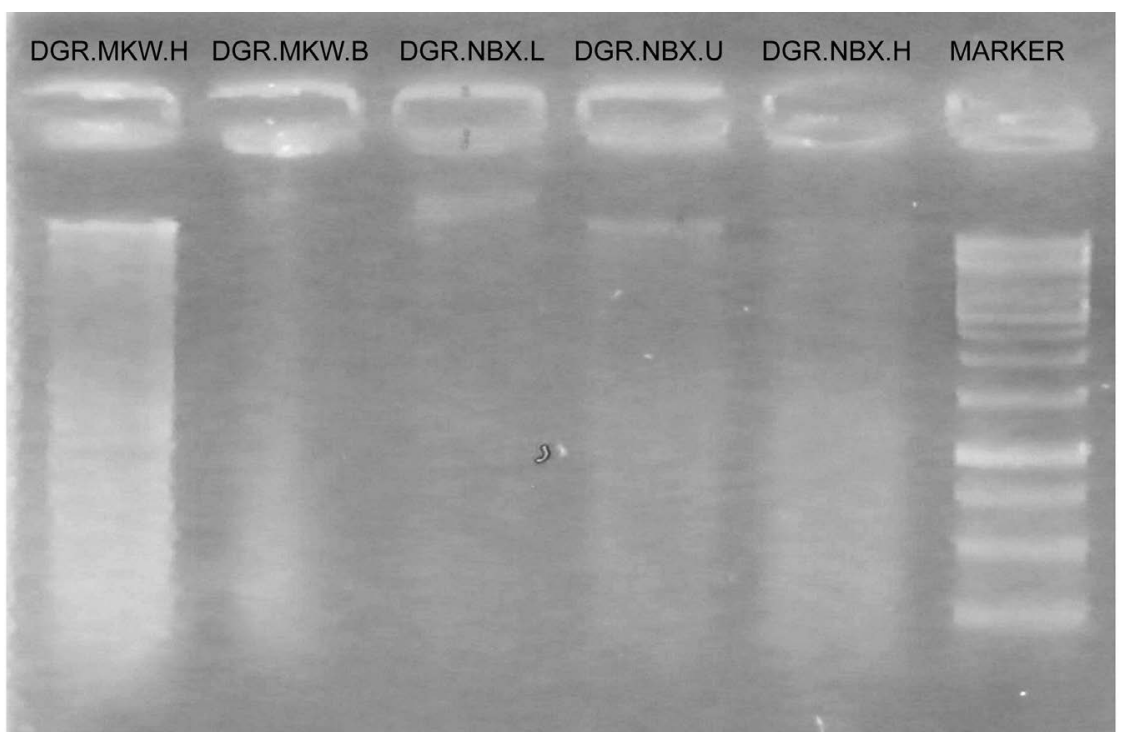

Figure 2. Ribbon Genome DNA from leaves itchy origin Nabire and Manokwari.

amplified by using primer Rbcl-Ar and Rbcl-Af, are sample DT.NBX.H, DT. NBX.U, DR.NBX.L and DR.MKW.H, meanwhile, samples DR.MKW.B not succeed in amplification (results not shown). The length amplicon obtained about 800 base pairs. It is seen by aligning the position of the sample DNA with DNA markers of known length.

\subsection{Phylogenetic Analysis}

Sequencing of the four samples of Laportea, is derived nucleotide sequences that encode genes Rbcl. The sequence is checked and adjusted (proof reading) with elektroferogram obtained, to ensure the correct sequence. The process of proof reading is based on the forward and reverse sequences of each sample. The quality of the sequences obtained was excellent, as indicated by the high peaks and clean from electroferogram.

The results alignment and the primary cutting edge, obtained along the 552 nucleotide base pairs. Of the four samples of Laportea, 17 points polymorphism obtained. The point of polymorphism is a nucleotide sequence that differs from one sequence to another. Based on the polymorphism, four samples can be classified into two haplotypes, a DNA sequence is said to be different haplotype when 


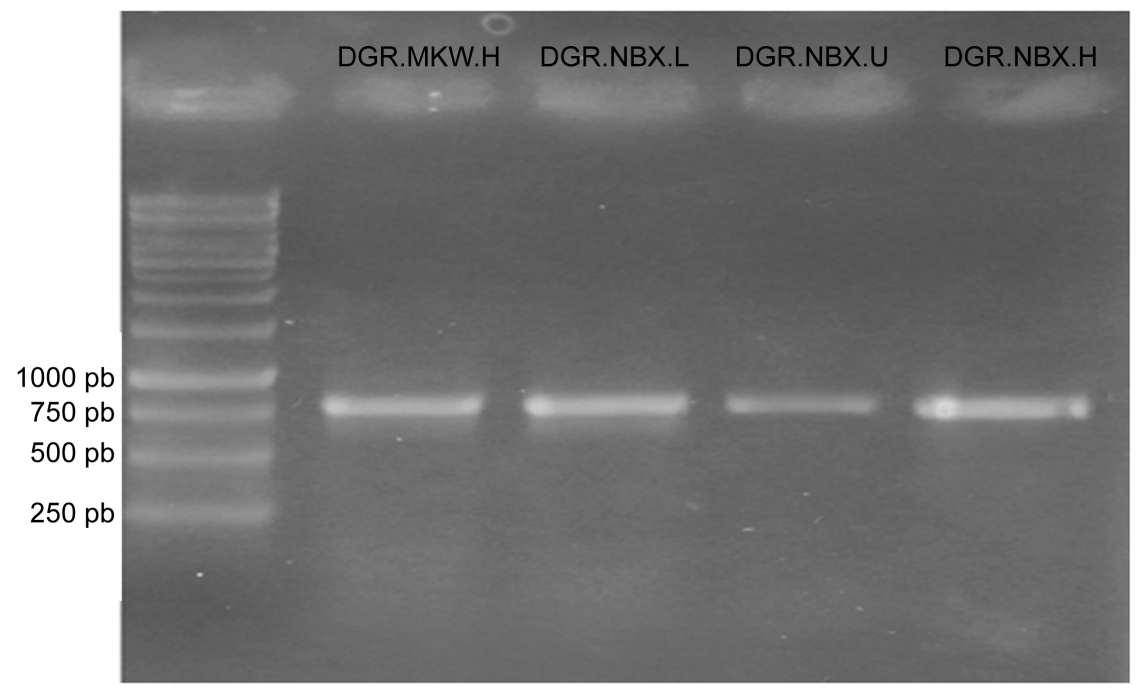

Figure 3. Results of electrophoresis of PCR products from leaf itch gene Rbcl origin Nabire and Manokwari.

there are one or more nucleotides different when compared with other sequences. The first consists of a sample haplotype DT_NBX_H, DT_NBX_U and DR_MKW_H, while the second is a sample DR_NBX_L haplotype. There were no nucleotide variations between samples of genes Rbcl green Laporeorigin of Nabire with leaves of Manokwari, like wise for Laporta leaf green and purple. Nucleotide variation is found (in the genes Rbcl) between the leaves with Laportea lateng others.

Nucleotide variation is found (in the genes Rbcl) between the itch lateng leaves and the others of itch leaf. The variations are the result of a point mutation in the form of transition (Ts) and Transvertions (Tv) (Table 2). Transition mutations are DNA mutations that occur due to changes in nucleotides of purine bases (adenine (A), guanine $(\mathrm{G})$ ) be a purine or pyrimidine bases (Cytosin $(\mathrm{C})$, Thymine $(\mathrm{T})$ ) be a pyrimidine. While transversion mutation occurs due to a mutation of purine bases (adenine $(A)$, guanine $(G)$ ) into pyrimidine (Cytosin $(C)$, Thymine (T)) or reverse. Details of the mutated nucleotide position transitions and tranversi presented in Table 2.

Analysis of the phylo genetic tree created using MEGA software 5 [7]. Based on morphological analysis, obtained the basic information that Laportea samples in this study belong to the genus of Laportea. Therefore, as a reference in the manufacture of the phylogenetic tree, use some sequences of genes Rbcl from NCBI. According to $\mathrm{Wu}$ et al. [11], uriticaceae family members can be grouped into three major clades. One clade of Laportea genus in which there is a third clade, in which there are genus Nanocnide,Uritica, Girardinia, Dendrocnide, Discocnide, Poikilospermum, Urera, Touchardia, Obetia and Laportea. Therefore, the phylo genetic tree made using gene Rbcl of genus-the genus are available at NCBI. A total of 420 base pairs of nucleotides that encode genes Rbcl of 89 sequences ( 4 samples of leaves itchy, one sequence out group, and 83 sequences from the family Uriticaceae selected from NCBI). The phylo genetic tree was made by the method of maxi- 
Table 2. Polymorphisms point of the fourth samples of Daun gatal.

\begin{tabular}{|c|c|c|c|c|c|c|c|c|c|c|}
\hline \multirow{2}{*}{ ID Sample } & \multirow{2}{*}{ Nama of Sample. } & \multicolumn{9}{|c|}{ Nucleotida position } \\
\hline & & 75 & 114 & 150 & 263 & 327 & 366 & 393 & 396 & 400 \\
\hline DT_NBX_H & D. Gatal Hijau & $\mathrm{C}$ & A & $\mathrm{T}$ & $\mathrm{T}$ & $\mathrm{T}$ & $\mathrm{C}$ & A & $\mathrm{C}$ & $\mathrm{T}$ \\
\hline DT_NBX_U & D. Gatal Ungu & $\mathrm{C}$ & A & $\mathrm{T}$ & $\mathrm{T}$ & $\mathrm{T}$ & $\mathrm{C}$ & A & $\mathrm{C}$ & $\mathrm{T}$ \\
\hline DR_NBX_L & D. Gatal Lateng & $\mathrm{T}$ & $\mathrm{C}$ & A & A & G & G & $\mathrm{C}$ & $\mathrm{T}$ & G \\
\hline \multirow[t]{2}{*}{ DR_MKW_H } & D. Gatal Hijau & $\mathrm{C}$ & A & $\mathrm{T}$ & $\mathrm{T}$ & $\mathrm{T}$ & $\mathrm{C}$ & A & $\mathrm{C}$ & $\mathrm{T}$ \\
\hline & Mutation & Ts & $\mathrm{Tv}$ & $\mathrm{Tv}$ & $\mathrm{Tv}$ & $\mathrm{Tv}$ & $\mathrm{Tv}$ & TV & Ts & $\mathrm{Tv}$ \\
\hline \multirow{2}{*}{ ID Sample } & \multirow{2}{*}{ Name of Sample } & \multicolumn{9}{|c|}{ Nucleotida position } \\
\hline & & 406 & 407 & 408 & 417 & 435 & 471 & 522 & 537 & \\
\hline DT_NBX_H & D. Gatal Hijau & A & $\mathrm{C}$ & $\mathrm{T}$ & $\mathrm{C}$ & $\mathrm{T}$ & $\mathrm{C}$ & G & A & \\
\hline DT_NBX_U & D. Gatal Ungu & A & $\mathrm{C}$ & $\mathrm{T}$ & $\mathrm{C}$ & $\mathrm{T}$ & $\mathrm{C}$ & G & A & \\
\hline DR_NBX_L & D. Gatal Lateng & G & $\mathrm{T}$ & $\mathrm{C}$ & $\mathrm{T}$ & $\mathrm{C}$ & $\mathrm{T}$ & A & $\mathrm{T}$ & \\
\hline DR_MKW_H & D. Gatal Hijau & A & $\mathrm{C}$ & $\mathrm{T}$ & $\mathrm{C}$ & $\mathrm{T}$ & $\mathrm{C}$ & G & A & \\
\hline \multicolumn{2}{|r|}{ Mutation } & Ts & Ts & Ts & Ts & Ts & Ts & Ts & $\mathrm{Tv}$ & \\
\hline
\end{tabular}

mum likelihood parameter K2P + G (Kimura 2 parameter and Gamma distribution). The meter is chosen from the test results the appropriate evolutionary model by using model test [10] in the MEGA 5. Bayesian Inference model with the smallest value is selected as the best model [12]. Bootstrapt 1000 replication method used to test the phylo genetic trees were created. Making the results presented in the phylo genetic tree in Figure 4, value of each branch boot strapt written on each base branching. This value indicates the support or the confidence level of each branch formed 1000 repetitions building the tree.

Phylogenetic tree in Figure 4 indicates that three samples of leaves itchy with ID DT.NBX.H, DT.NBX.U and DR.MKW.H are in the same clade. This indicates that based on data from three samples Rbcl gene is one species to the same. Although the morphology of bone samples DT.NBX.U has leaves and the underside of leaves are purple, but the nucleotide sequence of its gene Rbcl exactly, in addition, in the clade seen the clade of the genus group of Dendrocnidaespp, Laporteasp and Descocnidemexicana. Value the support of the establishment of branches between the sample and sequences spp Dendrocnidae very small at only $31 \%$. With the presence of several species are joined into one large clade and formed politomi, namely branching comb, accompanied by a low boot strapt indicates that the kinship of the three groups did not seen any real difference. This means that, Rbcl gene which is a DNA barcoding for plants could not distinguish between the third genus.

Samples DR.NBX.L, in phylogenetic, are in a clade with Laportea interupta, L. ruderalis and Urera sp. with bootstrapt $66 \%$. The third ramification of this species 


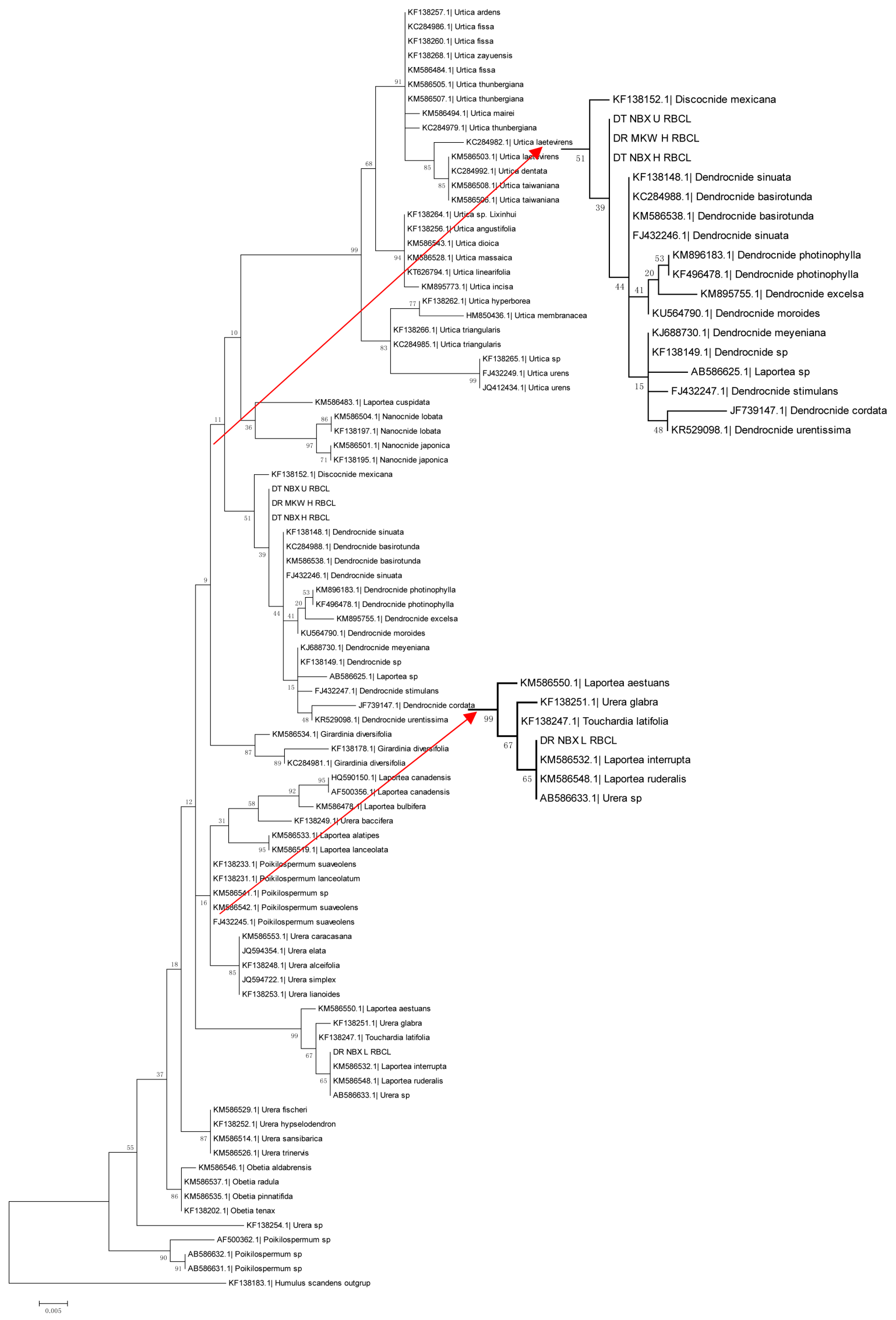

Figure 4. Phylogenetic tree. 
also are politomi, so the kinship of all three cannot be distinguished by using gene Rbcl. Based on morphological analysis, it appears that this sample is a sample of the species Laportea interupta. With the results of phylogenetic tree analysis shows that this sample are in a clade with L. interupta, so it can be sure that the species is L. intruptadarisampel, although in the clade there are other species. Therefore, it is necessary to do further research that examines the kinship and systematics of the group leaves from Papua itch by using some other loci, both chloroplast and nuclear DNA locus.

\section{Conclusions}

1) The nucleotide sequence of the gene Rbcl Laportea origin Nabire and Manokwari successfully determined the sequence with a total length reaching 552 base pairs.

2) Of the four samples, two obtained haplotype are Haplo Type 1 (DT.NBX.H, DT.NBX.U, DR.MKW.H) and Haplo Type 2 (DR.NBX.L).

3) The results of the phylo genetic tree analysis show samples at 1 in the same haplo type and clade sequences of the genus Dendrocnidespp, Discocnide, and Laportea, while the sample at 2 in the same haplotype clade with Laportea interupta, Laportea ruderalisand Urera sp.

4) Gen Rbcl of the results of this study cannot explain the systematic relationships of these samples to the extent of the species. Multigene analyses or multilocus necessary are able to explain the systematics of the group leaves itchy.

\section{Acknowledgements}

Thanks to the Project of Competitive Research Grant (Hibah Bersaing) Fiscal Year 2016 for providing and supporting the research financials. Gratitude is also extended to all who are involved in this work.

\section{References}

[1] Masyhud (2010) National Lokakarya Indonesia Medical Plant. Siaran Pers Kementrian Kehutanan Republik Indonesia. Juni 1, 2013.

[2] John, R. (1997) Common Forest Trees of Irian Jaya Papua Indonesia. Royal Botanical Garden, Kew. Inggris.

[3] Eva Susanty Simaremare (2014) Phytochemical Screnning of Itchy Leaves (Laportea decumana (Roxb.) Wedd). Pharmacy Journal, 11, 98-107. http://jurnalnasional.ump.ac.id/index.php/PHARMACY/issue/view/92/showToc

[4] Essiett, U.A., Edet, N.I. and Bala, D.N. (2011) Phytochemical and Physicochemical Analysis of the Leaves of Laporteaaestuans (Linn.) Chew and Laporteaovalifolia (Schumach.) Chew (Male Female). Asian Journal of Plant Science and Research, 1, 35-42.

[5] Karmawati, E., Effendi, D.S. and Wahid, P. (1996) Potential, Opportunity and Constraint for Increase Agroindustry of Medical Plant. Prosiding Forum Konsultasi Strategi dan Koordinasi Pengembangan Agroindustri Tanaman Obat. Balai Penelitian Tanaman Rempah dan Obat.

[6] Sudiarto, E.R., Pribadi, M., Rahardjo, H., Nurhayati, Rosita, S.M.D. and Yusron, M. 
(2002) Strengthening Farmer-Industry Linkage Forsustainable Utilization of Medicinal Plant Resources. 11 th International Conference on the Modernization of Traditional Chinese Medicine, Chengdu, 3-5 November 2002.

[7] Tamura, K., Peterson, D., Peterson, N., Stecher, G., Nei, M. and Kumar, S. (2011) MEGA5: Molecular Evolutionary Genetics Analysis Using Maximum Likelihood, Evolutionary Distance, and Maximum Parsimony Methods. Molecular Biology and Evolution, 28, 2731-2739. https://doi.org/10.1093/molbev/msr121

[8] World Health Organization [WHO] (2009) Medicinal Plants in Papua New Guinea. Manila. World Health Organization, Regional Office for the Western Pacific.

[9] Kress, W.J., Erickson, D.L., Jones, F.A., Swenson, N.G., Perez, R., Sanjur, O. and Bermingham, E. (2009) Plant DNA Barcodes and a Community Phylogeny of a Tropical Forest Dynamics Plot in Panama. Proceedings of National Academy of Sciences, USA, 106, 18621-18626. https://doi.org/10.1073/pnas.0909820106

[10] Levin, R.A., Wagner, W.L., Hoch, P.C., Nepokroeff, M., Pires, J.C., Zimmer, E.A. and Sytsma, K.J. (2003) Family-Level Relationships of Onagraceae Based on Chloroplast $r b c L$ and $n d h F$ Data. American Journal of Botany, 90, 107-115.

https://doi.org/10.3732/ajb.90.1.107

[11] Wu, Z.-Y., Monro, A.K., Milne, R.I., Wang, H., Yi, T.-S., Liu, J. and Li, D.-Z. (2013) Molecular Phylogeny of the Nettle Family (Urticaceae) Inferred from Multiple Loci of Three Genomes and Extensive Generic Sampling. Molecular Phylogenetics and Evolution Journal, 69, 814-827. https://doi.org/10.1016/j.ympev.2013.06.022

[12] Nei, M. and Kumar, S. (2000) Molecular Evolution and Phylogenetics. Oxford University Press, New York.

\section{Scientific Research Publishing}

\section{Submit or recommend next manuscript to SCIRP and we will provide best} service for you:

Accepting pre-submission inquiries through Email, Facebook, LinkedIn, Twitter, etc. A wide selection of journals (inclusive of 9 subjects, more than 200 journals)

Providing 24-hour high-quality service

User-friendly online submission system

Fair and swift peer-review system

Efficient typesetting and proofreading procedure

Display of the result of downloads and visits, as well as the number of cited articles

Maximum dissemination of your research work

Submit your manuscript at: http://papersubmission.scirp.org/

Or contact ns@scirp.org 